\title{
Big data analitikası texnologiyaları və fordi məlumatların təhlükəsizliyi problemləri
}

\author{
Şahanə Mansurova \\ AMEA İnformasiya Texnologiyaları İnstitutu, Bakı, Azərbaycan \\ depart3@iit.science.az
}

\begin{abstract}
Xülasə- Məqalədə Big Data dövründə fərdi məlumatların məxfiliyinin qorunması məsələləri tədqiq olunmuşdur. Böyük həcmli verilənlər insanların həyat tərzinə, iş və təhsilinə müsbət təsir etməklə bərabər, onlar eyni zamanda bir sira informasiya təhlükəsizliyi təhdidləri və problemləri ilə üzləşirlər. Buna görə də böyük verilənlər dövrünün qarşılaşdığı fərdi məlumatların təhlükəsizliyi problemləri böyük əhəmiyyət daşıyır. Big Data erasında fərdi məlumatların təhlükəsizliyinin qorunması məsələləri araşdırılmışdır. Sənaye 4.0 inqilabına təkan verən texnologiyaların fərdi məlumatlar üçün yaratdığı təhdidlər və bu texnologiyalarda fordi məlumat sizıntısına səbəb olan amillər göstərilmiş və onların aradan qaldırılması üçün həll yolları təklif olunmuşdur.
\end{abstract}

Açar sözlor-big data; informasiya tohlükasizliyi; Sonaye 4.0; fordi məlumatların təhlükəsizliyi; aşyaların İnterneti; süni intellekt.

\section{GİRIŞ}

Müasir informasiya və kommunikasiya texnologiyalarının (IKT) inkişafı və çoxsaylı sahələrə tətbiqi nəticəsində əsaslı dəyişikliklər baş vermişdir. Müasir dövrdə bu dəyişikliklərdən biri də fəaliyyət sahələrində toplanan verilənlərin həcminin böyük sürətlə artmasıdır. Bütün fəaliyyət sahələrində olduğu kimi elmdə də verilənlərin həcmi sürətlə artır. Emal edilən informasiyanın hazırki partlayışı dövründə bu fenomen "Big Data" adlandırılır. Elmdə böyük həcmli elmi verilənlərin sürətlə artmasına e-elmin inkişafi səbəb olur. Elmi verilənlər növü, həcmi, istifadə olunma tezliyi, ömür tsikli və $\mathrm{s}$. xüsusiyyətləri ilə fərqlənir. Araşdırmalarda əsasən 4 növ tədqiqat verilənləri xüsusi əhəmiyyətə malikdir: məlumat verilənləri, hesablama verilənləri, eksperimental verilənlər, müşahidə verilənləri. Həmin verilənlərin hər bir növü bu və ya digər dərəcədə konkret tədqiqatçı və ya tədqiqatçı qrupları ilə əlaqəlidir [1].

Big Data, verilənlərin potensial dəyərini araşdırmağı və nəhəng verilənlərin saxlanması və təhlili ilə iqtisadi və sosial inkişafa xidmət edir. Sənaye 4.0 İnqilabının meydana gəlməsi əşyaların İnterneti (Internet of Things - IoT), süni intellekt (SI), kiber-fiziki sistem (KFS) texnologiyalarının inkişafı ilə baglıdır və onların müxtəlif sahələrə tətbiqi də öz növbəsində verilənlərin müxtəlif mənbəli və formatlı olması potensialını artırır.

Böyük verilənlər dövrünün başlanması təkcə sosial tərəqqi üçün vacib imkanlar yaratmır, eyni zamanda, bu texnologiyalar cəmiyyətə bir çox informasiya təhlükəsizliyi təhdidlərini və fərdi məlumatların məxfiliyinin qorunması tələbini də gətirir. E-elm mühitinin də həll etdiyi məsələlərə görə təşkil olunduğu alt sistemlərində fərdi məlumatların qorunması prioritet məsələlərdən hesab olunur.

Beləliklə, Big Data texnologiyaları böyük potensiala malik olmaqla yanaş1, həm də müxtəlif fəaliyyət sahələrinə effektiv təsir göstərir. $\mathrm{Bu}$ texnologiyalar fərdi məlumatların təhlükəsizliyi baxımından ciddi problemlər yaradır. Verilənlərin toplanması, saxlanması və istifadəsi prosesində fərdi məlumatlar asanlıqla sızdırıla bilər və bunun da təyin edilməsi çətinləşər.

\section{BIG DATA VӘ İNFORMASIYA TӘHLÜKӘSIZLIYİ}

İKT-nin sürətli inkişafi kommunikasiya vasitələrinin çoxalmasına, yeni informasiya resurslarının yaranmasına, informasiyaya əlçatanlığın asanlaşmasına və s. səbəb olmuşdur. $\mathrm{Bu}$ isə öz növbəsində verilənlərin çox sürətli artımına gətirib çıxarır. Belə böyük həcmli verilənlərin analizi üçün ənənəvi texnologiyaların tətbiqi əlverişli deyil. $\mathrm{Bu}$ da yeni texnologiyaların inkişafı tələbini meydana gətirir. $\mathrm{O}$, faydaları ilə yanaşı artan inkişafı fonunda informasiya təhlükəsizliyi problemlərini də ortaya çıxarır.

Big datanın tətbiq olunduğu sahələrdən asılı olmayaraq ümumi xarakteristikaları var və bu xarakteristikalar əsas problemləri özündə əks etdirir. Big data konsepsiyasına iki cür yanaşmaq olar: böyük ölçülü verilənlər və informasiya texnologiyalarının yeni bir növü kimi. Bir sözlə, big data konsepsiyası böyük məlumatların toplanması və emalı üçün paylanmış hesablama resurslarının imkanlarından istifadə edən yeni texnologiyadır [2].

İnformasiya sisteminin normal fəaliyyət prosesinə müdaxilə və ya informasiyanı icazəsiz əldə etməyə cəhd edən kənar şəxslər və təşkilatlar da informasiya təhlükəsizliyinə mühüm təsir göstərirlər. İnformasiya təhlükəsizliyi məsələləri təkcə emal edilən informasiyanın əlyetənliyinin, tamlığının və konfidensiallığının təmin edilməsi ilə bitmir. Problemin siyasi, hüquqi, iqtisadi, psixoloji, kadr təminatı və s. aspektlorini də nəzərə almaq vacibdir [3]. Fərdi məlumatlar şəxsin kimliyini birbaşa və ya dolayısı ilə müəyyənləşdirməyə imkan verən istənilən məlumat toplusu olub, öz növbəsində-şəxsi, həssas, coğrafi və s. olmaqla növləndirilir [4]. Müasir dövrdə fərdi məlumatların məxfiliynin qorunması məsələləri tək milli deyil, eləcə də qlobal xarakter daşıyır. 


\section{“Informasiya tohlükosizliyinin aktual multidissiplinar elmi-praktiki problemlori” \\ V respublika konfransı, 29 noyabr 2019-cu il}

Big Data kontekstində fərdi məlumatlar çox vaxt İnternetdəki fərdi məlumatlarla əlaqələndirilir. Buna görə, fərdi məlumatları iki kateqoriyaya bölmək olar [5]:

- İnternetin yaranmasindan əvvəlki fərdi məlumatlar,

- İnternetin yaranmasından sonrakı fordi məlumatlar

Big data dövründə çoxsaylı fərdi məlumatlar davamlı olaraq artır və onların toplanması, yayılması və istifadəsi ilə əlaqədar risklərə aşağıdakıları misal göstərmək olar:

- Şəbəkə xidməti provayderi tərəfindən məlumatın əldə edilməsi,

- Haker və troyan təhdidləri,

- Qanunsuz məlumat dövriyyəsi.

İnformasiya təhlükəsizliyinin təmin edilməsində insanlarla yanaşı daha iki vacib komponent: proseslər və texnologiyalar iştirak edir [2]. Big Data texnologiyaları yeni müxtəlif mənbələrdən alınmış strukturlaşdırılmamış verilənlərin real zamanda emalını mümkün edir. $\mathrm{Bu}$ texnologiyalar tətbiq olunduğu sahələrdə inkişafa səbəb olmuşdur. Big Data texnologiyalarının tətbiqi fərdlər barəsində toplanan məlumatların və onların mənbələrinin hədsiz dərəcədə genişləndirilməsinə gətirib çıxarmışdır. $\mathrm{Bu}$ texnologiyalar sayəsində fərdi məlumatlardan sui-istifadə edilməsinin mənfi nəticələri təkcə ayrı-ayrı insanların şəxsi həyatlarının gizliliyinin pozulmasında deyil, ictimai həyatda, iqtisadiyyatda və siyasətdə də özünü göstərə bilər. Böyük məlumatlar kontekstində məlumatlar çox əlaqəlidir və məlumatların dərin təhlili müəyyən şəxslərin məxfilik məlumatlarını ifşa edə bilər [6]. $\mathrm{Bu}$ da insanların məlumat təhlükəsizliyi mövzusuna diqqətini artırır. Buna görə böyük məlumatların yaratdığı fərdi məlumat təhlükəsizliyi problemi diqqətdən kənarda qalmamalıdır .

\section{SəNAYE 4.0 VӘ BIG DATA}

Sənayede İKT-nin imkanlarının geniş miqyaslı tətbiqi "4-cü sənaye inqilabı" konsepsiyasını da öz bərabərində gətirdi. Bu inkişafla əlaqədar olaraq bir sıra ədəbiyyatlarda da "4-cü sənaye inqilabı" konsepsiyası barəsində bəhs edilməyə başlandı. Sənaye 4.0 inkişafına təkan verən əsas amilləri aşağıdakı kimi qeyd etmək olar [7]:

- informasiya və kommunikasiya texnologiyaları,

- $\quad$ kiber-fiziki sistemlər (KFS),

- Şəbəkə texnologiyaları,

- $\quad$ süni intellekt (Sİ),

- big data və bulud texnologiyaları,

- modelləşdirmə, virtualizasiya və simulyasiya,

- insan-kompüter qarşılıqlığı və əməkdaşlığı üçün vasitələr.
Dördüncü sənaye inqilabı miqyası, həcmi və mürəkkəbliyinə görə bəşəriyyətin bütün əvvəlki təcrübələrinin heç birinə bənzəmir. Onun süni intellekt, robototexnika, nanotexnologiya, biotexnologiya və s. daxil olmaqla ən geniş sahələrdə heyrətamiz texnoloji sıçrayışı yaradır. Bu texnoloji sıçrayışın gətirdiyi problemlərdən on başlıcası fərdi məlumatların təhlükəsizliyi və məxfiliyinin qorunması məsələləridir. Dördüncü sənaye inqilabına təkan verən yeni texnologiyalarda məlumatların məxfiliyinin qorunması məsələlərinə dair bir sıra problemlər tədqiq olunmuş və onlar aşağıda qeyd edilmişdir.

\section{A. Oşyaların Interneti}

Oşyaların İnterneti mahiyyətcə İnternetə qoşulan obyekt, maşın və qurğulardan verilənlərin toplanması, saxlanması, emalı və analizi texnologiyasıdır [8]. Müxtəlif istifadə sahələrində IoT məlumatların məxfiliyi bir sıra tədqiqatlarda araşdırılmışdır [9-11]. Gələcək qlobal IoT şəbəkəsi məxfiliklə bağl1 problemlər gətirir. IoT-un tətbiqində məlumat məxfiliyinin pozulması səbəblərinə aşağıdakıları göstərmək olar:

- İlkin "emal olunmamış” verilənlərin saxlanması;

- Cihazla təminat;

- $\quad$ Enerji məhdudiyyəti;

- Şifrləmə məhdudiyyəti;

- Standartlaşdırmanın qeyri-kafi təşkili;

- Cihaz səviyyəsində məlumat toplama və paylaşma perspektivi baxımından İoT cihaz istehsalçısından daha az məlumat əldə edilməsi.

\section{B. Süni intellekt (Artificial Intelligence - AI)}

Süni intellekt məlumatların məxfiliyinin pozulması siyahısında ön sıradadır. [12]-də Sİ-in gizlilik riski araşdırılmışdır. Real zamanda görüntünün emalı insanın şəxsiyyətini müəyyənləşdirir və milyonlarla fərdi məlumatların məxfiliyinin pozulmasına səbəb olur $[13,14]$. Süni intellekt və robototexnikada verilənlərin məxfiliyi mövzusundak1 əsas problemlərə aşağıdakıları aid etmək olar:

- Sİ əsaslı texnologiyalar üçün məxfilik standartlaşdırılması yoxdur,

- İstifadəçidən razılıq toplamaq səmərəsizdir,

- Sİ qərarının qəbuluna nəzarət edilməlidir.

\section{Kiber-fiziki sistemlar (Cyber-Physical System-CPS)}

Sənaye 4.0-1n əsas məqsədi daha sürətli olmaq və istehsalın səmərəliliyini artırmaqdır. Sənaye 4.0 kontekstində istifadə olunan əsas texnologiya KFS-dir [15]. KFS müxtəlif fiziki obyektlər, süni altsistemlərdən ibarət olan və müxtəlif sensorlardan gələn əks əlaqələrdən istifadə etməklə idarə edilən sistemlərdir. KFS-nin işləməsi hesablama və fiziki proseslərin inteqrasiyası prinsipinə əsaslanır, yəni fiziki obyektlər sistemin bir hissəsini təşkil edir. KFS müstəqil və ağıllı bir sistem 


\section{“Informasiya tohlükosizliyinin aktual multidissiplinar elmi-praktiki problemlori” \\ V respublika konfransı, 29 noyabr 2019-cu il}

yaradan və buna görə də fərqli və fiziki cəhətdən uzaq olan subyektlər arasında inteqrasiyanı asanlaşdıran və müxtəlif imkanlar yaradan texnologiyaların toplusudur. $\mathrm{Bu}$ sistem üç ardicıl ssenariyə imkan verir: məlumatların generasiyası və əldə edilməsi, əvvəllər əldə edilmiş məlumatların hesablanması və birləşdirilməsi və nəhayət, qərar dəstəyi.

Ümumiyyətlə, KFS konfidensiallı̆̆1 passivdir [16]. Tədqiqatda KFS-də konfidensiallığın pozulmasının iki yolu qeyd edilir:

- Fiziki səviyyədə: Bu cür gizlilik hücumu sistemin fiziki xüsusiyyətlərinə birbaşa müdaxilə edir. Məsələn, səhiyyə çipinin imkanlarını dəyişdirmək.

- Kiber səviyyədə: Kompüter virusu, proqram təminatı və şəbəkə hücumları KFS-ə kiber hücumdur. Məsələn, saxta sensor məlumatları.

\section{Bulud va böyük verilanlar (Cloud and Big Data)}

Böyük məlumatlar, șübhəsiz ki, Sənaye 4.0-də tətbiq olunan ən vacib texnologiyalardan biridir. Buna səbəb ağıllı alqoritmlərdən istifadə edərək strukturlaşdırılmış və strukturlaşdırılmamış verilənlərin geniş şəkildə toplanması, emal edilməsi və analiz edilməsidir.

Digər vacib bir texnologiya açıq sistemlərdə çox böyük həcmli verilənləri idarə etməyə və real vaxt rejimində əlaqəni təmin etməyə imkan verən bulud hesablamalarıdır. Bulud hesablamalar dünyanın istənilən yerindən istənilən vaxtda məlumat əldə etmok imkanı verir, bu da rahatlı̆̆ı artırır [17]. Ağıllı fabrikdə məlumatlar rəqəmsal şəkildə ötürülür, buna görə kibertəhlükəsizlik yeni sənaye inqilabında əsas rol oynayır. İnformasiya təhlükəsizliyi sistemləri digər texnologiyaların potensialından tam istifadə üçün vacibdir.

Bulud hesablamalarının bu gün təşkilatlar üçün yaratdığı ən böyük və ən kritik təhdid həssas və şəxsi verilənlərin, informasiyanın həm qəsdən, həm də qəsdsiz olaraq itkisidir [14].

Big Data araşdırması Sİ-nin iştirakından sonra sürətli, effektiv və dəqiq oldu. Big Data və Buludda olan əsas problemlər bunlardir:

- Məlumatların şifrələnməsi;

- Fiziki həssasliq;

- Qeyri-müəyyən verilənlərin paylaşımı və mübadiləsi siyasəti;

- Böyük ölçülü verilənlərin toplanması.

\section{BIG DATA ERASINDA FORDİ MOLUMAT TӘHLÜKӘSIZLIYININ KONSEPTUAL MOSӘLӘLӘRİ}

Dünya ölkələrinin təcrübəsində informasiyanın qorunmas1 aktual məsələlərdən hesab olunur. İnformasiya təhlükəsizliyinin təmin olunması sahəsində fərdi məlumatların mühafizəsi mühüm problemlərdən biridir. Bu problemin həlli istiqamətində zəruri tədbirlərin həyata keçirilməsi məqsədi ilə milli normativ-hüquqi bazanın, eləcə də beynəlxalq hüquqi mexanizmlərin formalaşdırılması olduqca əhəmiyyətlidir. Burada məsələyə ayr1-ayrı ölkələr kontekstində deyil, beynəlxalq qlobal informasiya təhlükəsizliyi kontekstində yanaşmaq lazımdır.

Böyük məlumatlar dövrünün gəlişi fərdi məlumatların məxfiliyinin qorunması ilə bağlı cəmiyyətdə yaranmış təhlükələrin aradan qaldırılması yollarını şərtləndirir. Beynəlxalq təcrübədə ortaya qoyulan bir sira tələblərin ölkəmiz üçün də reallaşdırılması mühüm məsələlərdəndir. Bu tələbləri aşağıda qeyd olunduğu kimi növləndirə bilərik:

- Cari vəziyyətə uyğun olaraq hüquqi-normativ bazanın daim təkmilləşdirilməsi;

- Vətəndaşların maarifləndirilməsi və onlarda informasiya təhlükəsizliyi mədəniyyətinin tərkib hissəsi kimi fərdi məlumatların təhlükəsizliyi mədəniyyətinin formalaşdırılması (sosial şəbəkələr və s.).

Fərdi məlumatların təhlükəsizliyində həm təşkilati, həm hüquqi, həm də texnoloji məqamlar var və bunlar bir-birindən asılı olaraq inkişafdadır. Lakin texnologiyanın daha sürətli inkişafı bu inkişaf üsullarını dəyişir və yeni üsulların yaranmasına səbəb olur, bəzi üsulların köhnəlib yararsız olmasına gətirib çıxarır. Ona görə də hüquqi-normativ baza inkişafa uyğun olaraq daim təkmilləşdirilməlidir.

Cəmiyyətin informasiya fəaliyyətinin artması ilə informasiya təhdidlərinin sayı da artacaq. $\mathrm{Bu}$ təhdidlərin qarşısının alınması məqsədi ilə əhalinin məlumatlılıq səviyyəsinin yüksəldilməsi və maarifləndirilməsi istiqamətində tədbirlər görmək lazımdır. Tədris vasitələrinin köməyi ilə fərdi məlumatların təhlükəsizliyi mədəniyyətinin formalaşdırılması kütləvi şəkildə həyata keçirilir.

Böyük məlumatlar dövründə yaradılan onlayn media insanlararası ünsiyyət üçün ən vacib məcralardan biri olmuşdur. Verilənlər haqqundakı informasiyaya olan nəzarətin gücləndirilməsi son dərəcə vacib məsələlərdəndir. İlk olaraq məlumatlara nəzarəti və idarəetməni gücləndirmək və anonim sosial media üçün şəbəkə məlumatlarını anonim olaraq qorumaq; sonra fərdi məlumat təhlükəsizliyinin cinayətkarlar tərəfindən istifadə edilməməsini və daha böyük itki verməməsini təmin etmək üçün sosial informasiyaya nəzarət və onu idarə etmək lazımdır. Bundan əlavə, istifadəçilərin təhlükəsizlik tədbirləri barəsindəki maarifləndirilməsini artırmaq və şəxsi vacib məlumatların doldurulmasını minimuma endirmək üçün özünü qorumaq və ehtiyatlı davranmağa ehtiyac duyulur. Nəhayət, hökumət ən q1sa müddətdə böyük məlumatların tətbiqi üçün daha yaxş1 qaydaları və tənzimlənmələri təqdim etməli və hüquqi aspektləri gücləndirməlidir.

\section{NəTİCO}

Böyük məlumatların inkişafı kontekstində fərdi məlumatların təhlükəsizliyi ölkə və cəmiyyətin inkişafı üçün vacib strateji mövzu halına gəlmişdir. Ancaq səhv idarəetmə, haker hücumları və şəbəkə sisteminin təhlükəsizlik məsələlərindəki çatışmazlıqları səbəbi ilə fərdi məlumatlar 


\section{“Informasiya tohlükosizliyinin aktual multidissiplinar elmi-praktiki problemlori” V respublika konfransı, 29 noyabr 2019-cu il}

həmişə məxfiliyin pozulması ehtimalı ilə qarşılaşır. Müasir inkişaf tendensiyalarına əsasən milli təhlükəsizliyin təmin edilməsi sistemində fərdi məlumatların təhlükəsizliyi məsələsinin rolunun gələcəkdə daha da artacağını görmək olar. Big data məlumatlarının təhlükəsizliyi və məxfiliyinin qorunmasını həyata keçirmək üçün yalnız çox sayda peşəkar fərdi informasiya təhlükəsizliyi texnologiyası deyil, eyni zamanda ölkəmizdəki vətəndaşların məxfiliyinin qorunması ilə bağlı maarifləndirilməsinin gücləndirilməsi lazımdır ki, məlumatların məxfiliyi ilə bağlı təhlükəsizlik tədbirləri həyata keçirilə bilsin.

\section{İSTINADLAR}

[1] R.M.Oliquliyev, R.Q.Đləkbərov, T.X.Fətəliyev, Elektron elm: cari vəziyyəti, problemləri va perspektivləri, İnformasiya Texnologiyaları Problemləri, 2015, №2, səh.4-15.

[2] Md Mehedi Hassan ONIK, Chul-Soo KIM, Jinhong, "Personal Data Privacy Challenges of the Fourth Industrial Revolution" ICACT, 2019, pp.635-638

[3] R.M.Oliquliyev, Y.N.İmamverdiyev, "İnformasiya təhlükəsizliyinin humanitar aspektləri” İnformasiya təklükəsizliyinin multidissiplinar problemləri üzrə II respublika elmi-praktiki konfransı. Bakı, 2015, S. 912.

[4] Fordi məlumatlar haqqında Azərbaycan Respublikasının Qanunu. 11 may 2010-cu il.

[5] Cheng Chi1, Tengyu Liu, Xiaochen Yu, Shuo Zhang, and Shuo Shi, "Research on the Security of Personal Information in the Era of Big Data" AICON ,2019, LNICST 287, pp. 107-114.

[6] Y. İmamverdiyev, "Big data və fərdi məlumatların təhlükəsizliyi," Big data: imkanları, multidissiplinar problemləri va perspektivləri I respublika elmi-praktiki konfrans1, 2016, s. 109-113.

[7] H.Kinzel, "Industry 4.0 - Where does this leave the Human Factor?" https://www.researchgate.net/publication/308614137_Industry_40__Where_does_this_leave_the_Human_Factor.

[8] T.X.Fətəliyev, Ş.A.Mehdiyev, "Böyük həcmli elmi verilənlərin menecmenti və emal texnologiyalarının tədqiqi" İnformasiya comiyyəti problemləri,2019, No 2, s. 60-70.

[9] M.Conti, A.Dehghantanha, K.Franke, and S.Watson, "Internet of Things security and forensics: Challenges and opportunities" Elsevier, 2018.

[10] M. H.Miraz, M. Ali, P. S. Excell, and R. Picking, "A review on Internet of Things (IoT), Internet of everything (IoE) and Internet of nano things (IoNT)," Internet Technologies and Applications (ITA), 2015, pp. 219224.

[11] M. M. H. Onik, N. Al-Zaben, J. Yang, and C.-S.Kim,"Privacyof Things ( PoT ): Personally Identifiable Information Monitoring System for
Smart Homes" in Proceedings of Symposium of the Korean Institute of communications and Information Sciences, 2018, pp. 256-257.

[12] I. Priyadarshini, "Cyber Security Risks in Robotics" in Cyber Security and Threats: Concepts, Methodologies, Tools and Applications, IGI Global, 2018, pp. 1235-1250.

[13] Z. Qin, J.Weng, Y. Cui, and K. Ren, "Privacy-Preserving Image Processinginthe Cloud"IEEE Cloud Comput, vol. 5, no. 2, 2018, pp. 4857.

[14] Z. Xia, Y. Zhu, X. Sun, Z. Qin, and K. Ren, "Towards privacypreserving content-based image retrieval in cloud computing" IEEE Trans. Cloud Comput, vol. 6, no. 1, 2018, pp. 276-286.

[15] Germany Trade and Invest. Industrie 4.0: Smart manufacturing for the future. 2014. Available from: http://www.gtai.de/GTAI/Content/EN/Invest/_SharedDocs/ Downloads/GTAI/ Brochures/Industries/industrie4.0-smartmanufacturing-for-the-future-en.pdf

[16] J. Giraldo, E. Sarkar, A. A. Cardenas, M. Maniatakos, and M. Kantarcioglu, "Security and privacy in cyber-physical systems: A surveyofsurveys"IEEE Des. Test, vol. 34, no. 4, 2017, pp. 7-17.

[17] Z. Haiping, L. Yu, L. Qin, R. Yunqing. Cloud service platform for big data of manufacturing. Applied Mechanics and Materials. 2014;456:178183. www.scientific. net/AMM.456.178.

\section{BIG DATA ANALYTICS AND PERSONAL DATA SECURITY ISSUES}

Shahana Mansurova

Institute of Information Technology of ANAS, Baku, Azerbaijan

$$
\text { depart3@iit.science.az. }
$$

Abstract - The article explores the privacy protection issues of personal information for era of Big Data. In addition to having a positive impact on people's lifestyle, work and education, Big Data faces a range of information security threats and challenges. Therefore, the security issues of the personal data faced by the era of Big Data are 0of great importance. The security problems of personal data has been investigated in the era of Big Data. The threats to personal data posed by technologies that spurred the Industry 4.0 revolution and factors leading to leakage of personal data in these technologies have been shown and solutions have been proposed to overcome these factors.

Keywords - big data; information security; Industry 4.0; personal data security; Internet of Things; Artificial Intelligence. 